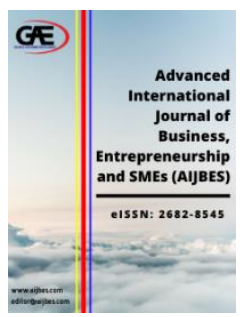

\author{
Advanced International Journal of Business, \\ Entrepreneurship and SMEs (AIJBES) \\ Journal Website: http://aijbes.com/ \\ eISSN: 2682-8545
}

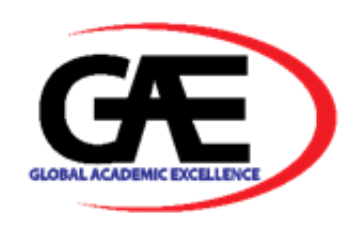

\title{
MODELING RESIDENTIAL PROPERTY CONSUMERS' CHOICE: EVIDENCE FROM THE PHILIPPINES
}

\author{
Jose Mari M. Lee ${ }^{1 *}$, Eduardo G. Ong ${ }^{2}$ \\ 1 University of Santo Tomas Graduate School, Philippines \\ Email: leejosemari@gmail.com,jmlee@ ust.edu.ph, josemari.lee.gs@ust.edu.ph \\ 2 University of Santo Tomas Graduate School, Philippines \\ Email: dregong2010@yahoo.com \\ * Corresponding Author
}

\begin{abstract}
Article Info:
Article history:

Received date: 07.05 .2020

Revised date: 13.06 .2020

Accepted date: 15.06 .2020

Published date: 15.06.2020

\section{To cite this document:}

Lee, J. M. M., \& Ong, E. G. (2020). Modeling Residential Property Consumers' Choice: Evidence from the Philippines. Advanced International Journal of Business, Entrepreneurship and SMEs, 2 (4), 26-35.
\end{abstract}

DOI: $10.35631 / A I J B E S .24003$.

\begin{abstract}
:
The study aims to investigate the relationships between the demographic profile and consumers' choice particularly price, location, safety and security, facilities and amenities, and exclusivity towards purchase intention of residential property in the Philippines. With the Association of Southeast Asian Nations (ASEAN) Economic Community, the Philippines is viewed by various experts to be in good standing to lead in the area's property growth. Descriptive-Causal was utilized in the study. The respondents were 400 potential residential property buyers from any of the top 10 real estate developers in the Philippines. The researcher used a purposive sampling method. The data collected through a self-constructed survey questionnaire was entered and analyzed using SPSS and AMOS. The findings of the study showed that the demographic characteristics have a direct effect on consumers' choice factors. It also revealed that consumers' choice factors have a direct effect on purchase intention. The researcher proposed an emerging model of the causal relationships between the demographic profile and consumers' choice factors towards purchase intention of residential property in the Philippines.
\end{abstract}

Keywords:

Consumers' Choice, Philippines, Real Estate, Residential Property, Structural Equation Modeling

\section{Introduction}

With the Association of Southeast Asian Nations (ASEAN) Economic Community, the Philippines is viewed by various experts to be in a good situation to lead in the region's property growth because of its young residents and English-language proficiency, nevertheless success can be attained by employing positive changes, starting with infrastructure (Lamudi, 2016). To fascinate and take benefit of the enormous potential market, real estate developers must satisfy Copyright (C) GLOBAL ACADEMIC EXCELLENCE (M) SDN BHD - All rights reserved 
the residential property buyers by marketing the desired features of the products as identified by the market (Nasar \& Manoj, 2015).

The relationships between demographic profile of the respondents and consumers' choice factors specifically price, location, safety and security, facilities and amenities, and exclusivity towards purchase intention of residential property in the Philippines have not yet been elucidated. The researcher examined the significant relationships between demographic profile and consumers' choice particularly price, location, safety and security, facilities and amenities, and exclusivity towards purchase intention of residential property in the Philippines. Based on the findings of the study, the researcher proposed a model for the consumer behavior of residential properties in the Philippines.

\section{Literature Review}

\section{Consumers' Choice Factors}

Buying real estate is a multifaceted procedure of formulating decision demanding consumers to undergo a series of stages (Tine, 2001; Johnson, 1974, as cited in Iman, Pieng, \& Gan, 2012). Identifying the factors that impact consumers to select residential property are important on advertising, scheduling, advancement and positioning real estate (Phungwong, 2010; Numraktrakul, Ngarmyarn \& Panichpathom, 2012, as cited in Al-Nahdi, Habib \& Albodour, 2015). Study identified 5 consumers' choice factors particularly price, location, safety and security, facilities and amenities, and exclusivity that affect the purchase intention of residential property buyers in the Philippines.

\section{Price}

Buying a Philippines' residential property is an enormous and lasting asset. The primary concern to contemplate before purchasing residential property is the ratio of debt to income. Financial intermediaries like banks or Pag-IBIG (Pagtutulungan sa Kinabukasan, Ikaw, Bangko, Industria at Gobyerno) will be paying the residential property purchase, it comes with 30 years maximum repayment for the Pag-IBIG depending to the type of property bought (Adrian, 2018). The price range and availability of loan were found to be the utmost significant by residential property buyers (Kumar \& Khandelwal, 2018). Study showed that $16-20$ years is the desired period for the residential property loan (Vijayakumar \& Subburaj, 2010).

\section{Location}

The worth of access to universities, shops, parks and transportation facilities is observed in the market price of the house (Brennan, Olaru, \& Smith, 2014). A planned location will influence consumer fulfillment in purchasing (Pangenggar, Hidayat, \& Sendhang, 2014, as cited in Rachmawati, Shukri, Azam, \& Khatibi, 2019). Furthermore, qualities of a building are being observed as one of the most vital facets of housing and provision of good and quality living (Salleh, 2008, as cited in Masri, Nawawi, \& Sipan, 2016).

\section{Safety and security}

Residential property buyer considers location of residential property with security concern at that area, which crime control and safety program are all involved (Liew \& Haron, 2013). The generalization of individuals would reasonably not live in an area where their safety, condition and security are under risk (Dung-Gwom, 2007, as cited in Aliyu, Kasim, \& Martin, 2012). Other study stated that a fenced and safeguarded residential property appears with higher fee by installing closed-circuit television (CCTV) and placing security guards (Salleh, Zoher, Mahayuddin, \& Abdul, 2015). 


\section{Facilities and amenities}

Residential property buyers prefer development which contains small city, parking lot, community playground, lobby, elevator and back-up power facilities, stockroom, shopping center, learning centers, swimming pools, fitness center, etc. (Khaled, et al., 2012; Zadkarim \& Emari, 2011; Barua, Mridha \& Khan, 2010, as cited in Kamal \& Pramanik, 2015a). Study showed that amenities is the most imperative factor in choosing a residential property (Manivannan \& Somasundaram, 2014). These are structures of a real estate property that make it a desirable location for residential, commercial, and recreational development, exemplifying the ideas of attractiveness, appeal, seemliness, and opportunity for improving one's quality of life (Myers, 2007; Smith, 1974, as cited in Buckman, Trivers, Kayanan, \& Black, 2017).

\section{Exclusivity}

The growing demand for residential property is based on stunning view, extraordinary scenery, exclusivity, natural beauty, fresh air and lack of suitable flat area (Sew \& Chin, 2000, as cited in Salleh, Zoher, Mahayuddin, \& Abdul, 2015). Other study also entails that a family's residential property purchasing decisions are correlated with location choice, workplace, house type, property size, society ties and neighbourhood characteristics (Wong, 2002, as cited in Omagwa \& Aduda, 2015). Likewise, residential property buyers were prepared to purchase a housing that has good neighborhood at a finest price (Tan, 2011).

\section{Purchase Intention}

Purchase intention is a usual potent action and it is frequently used to predict response behavior (Kotler, 2000, as cited in Ticoalu \& Tielung, 2015). Wu and Teng (2011) defined purchase intention as consumer likely in preparation to buying a specific product in the future.

\section{Research Objective}

1. To investigate the proposed model using Structural Equation Modeling (SEM).

\section{Research Question}

1. What can be the proposed model for the consumer behavior of residential property?

\section{Research Paradigm}

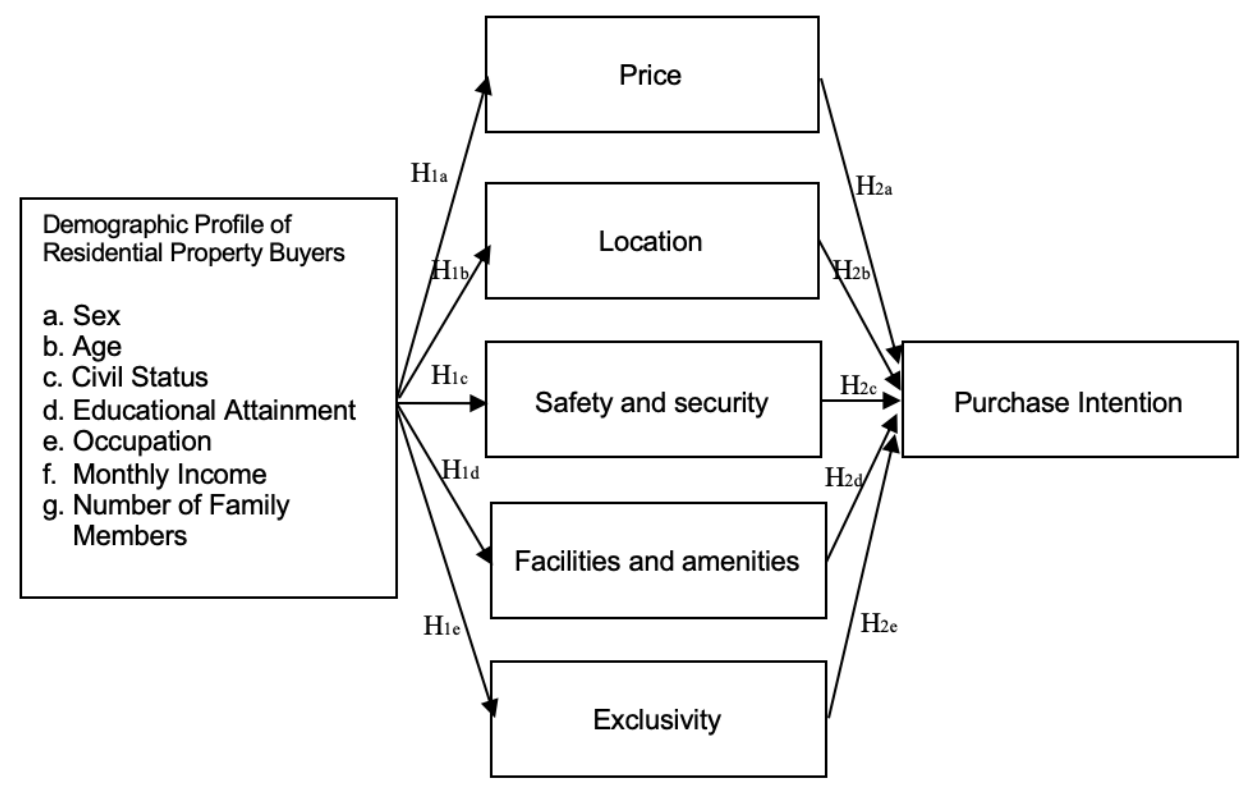

Figure 1. Conceptual Framework 
The illustration shows the relationship among the demographic profile and consumers' choice such as price, location, safety and security, facilities and amenities, and exclusivity towards purchase intention of residential property in the Philippines. Based on the findings of the study, the researcher proposed a model for the consumer behavior of residential properties in the Philippines.

\section{Hypotheses}

In order to realize the objectives of the study, the researcher tested the following hypotheses at 0.05 level of significance:

$H_{l a}$. Demographic characteristics of the respondents has significant effect on the consumers' choice in terms of price.

$H_{l b}$. Demographic characteristics of the respondents has significant effect on the consumers' choice in terms of location.

$H_{l c}$. Demographic characteristics of the respondents has significant effect on the consumers' choice in terms of safety and security.

$H_{l d}$. Demographic characteristics of the respondents has significant effect on the consumers' choice in terms of facilities and amenities.

$H_{l e}$. Demographic characteristics of the respondents has significant effect on the consumers' choice in terms of exclusivity.

$H_{2 a}$. Price of residential property positively affects the purchase intention of the respondents.

$H_{2 b}$. Location of residential property positively affects the purchase intention of the respondents.

$H_{2 c}$. Safety and security of the residential property positively affects the purchase intention of the respondents.

$H_{2 d}$. Facilities and amenities of the residential property positively affects the purchase intention of the respondents.

$H_{2 e}$. Exclusivity of the residential property positively affects the purchase intention of the respondents.

\section{Research Methodology}

The survey questionnaires were distributed online to 400 potential residential property buyers from any of the top 10 real estate developers in the Philippines. The researcher used purposive sampling method. Respondents should meet the following criterion: (1) Respondents must be 18 years old and above; (2) Respondents must have work; and, (3) Respondents must have plans to buy residential property from any of the top 10 real estate developers in the Philippines. If any of the criteria answered "no", thus the respondent is not qualified answering the survey questionnaire. On the other hand, if criteria answered with a "yes", then the respondent would be requested to complete the survey.

\section{Results and Discussion}

To show the acceptability of the emerging model as compared to the hypothesized model, the table shows a list of model fit indices. Table 1 depicts the model fit statistics of the resulting model specifically the $\chi^{2} / \mathrm{df}(\mathrm{CMIN} / \mathrm{df})$, root mean square error of approximation (RMSEA), comparative fit index (CFI), normed-fit indices (NFI) and incremental fit indices (IFI). The value 1.585 of $\chi^{2} / \mathrm{df}$ stresses compatibility of the emerging model. The RMSEA value of 0.038 coincides within the 0.08 and below acceptable range which associates the fitness of the proposed model. CFI, NFI and IFI with $0.961,0.903$ and 0.962 values, respectively, falls within the acceptable level of 0.90 , which indicates a good model fit of the proposed model. 
Table 1: Model Fit Indices of Hypothesized and Emerging Model

\begin{tabular}{lccc}
\hline Model Fit Indices & $\begin{array}{c}\text { Hypothesized } \\
\text { Model }\end{array}$ & $\begin{array}{c}\text { Emerging } \\
\text { Model }\end{array}$ & $\begin{array}{c}\text { Recommended } \\
\text { Value }\end{array}$ \\
\hline$\chi^{2 / d f(C m i n / d f) ~}$ & 4.286 & $\mathbf{1 . 5 8 5}$ & $\leq 3.00$ \\
Root Mean Square Error of & & & \\
Approximation (RMSEA) & 0.091 & $\mathbf{0 . 0 3 8}$ & $\leq 0.08$ \\
Comparative Fit Index (CFI) & 0.772 & $\mathbf{0 . 9 6 1}$ & $\geq 0.90$ \\
Normed Fit Index (NFI) & 0.723 & $\mathbf{0 . 9 0 3}$ & $\geq 0.90$ \\
Incremental Fit Index (IFI) & 0.773 & $\mathbf{0 . 9 6 2}$ & $\geq 0.90$ \\
\hline
\end{tabular}

Sources: Hair et al. (2010)

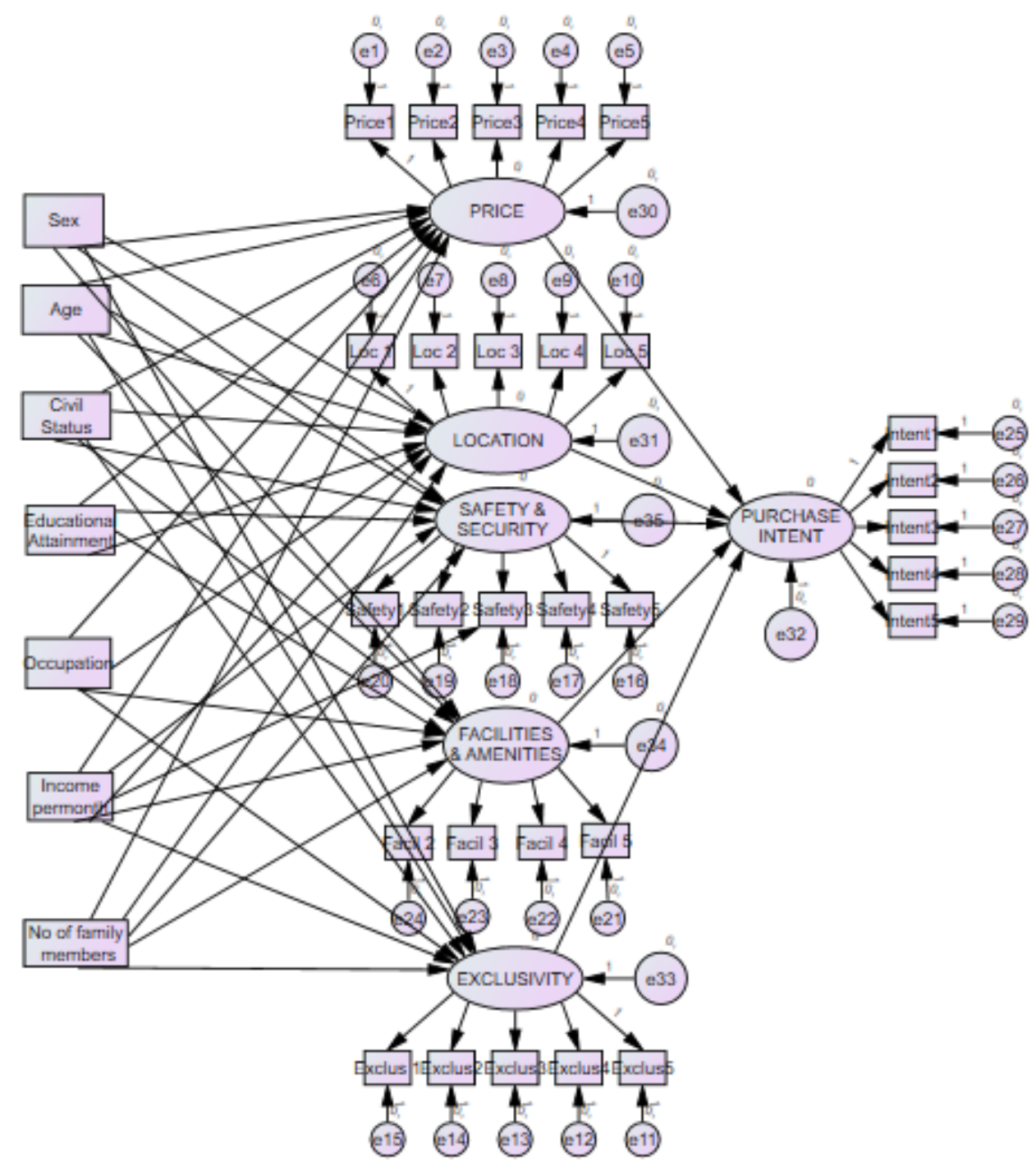

Figure 2. Hypothesized Model with Specific Variables 


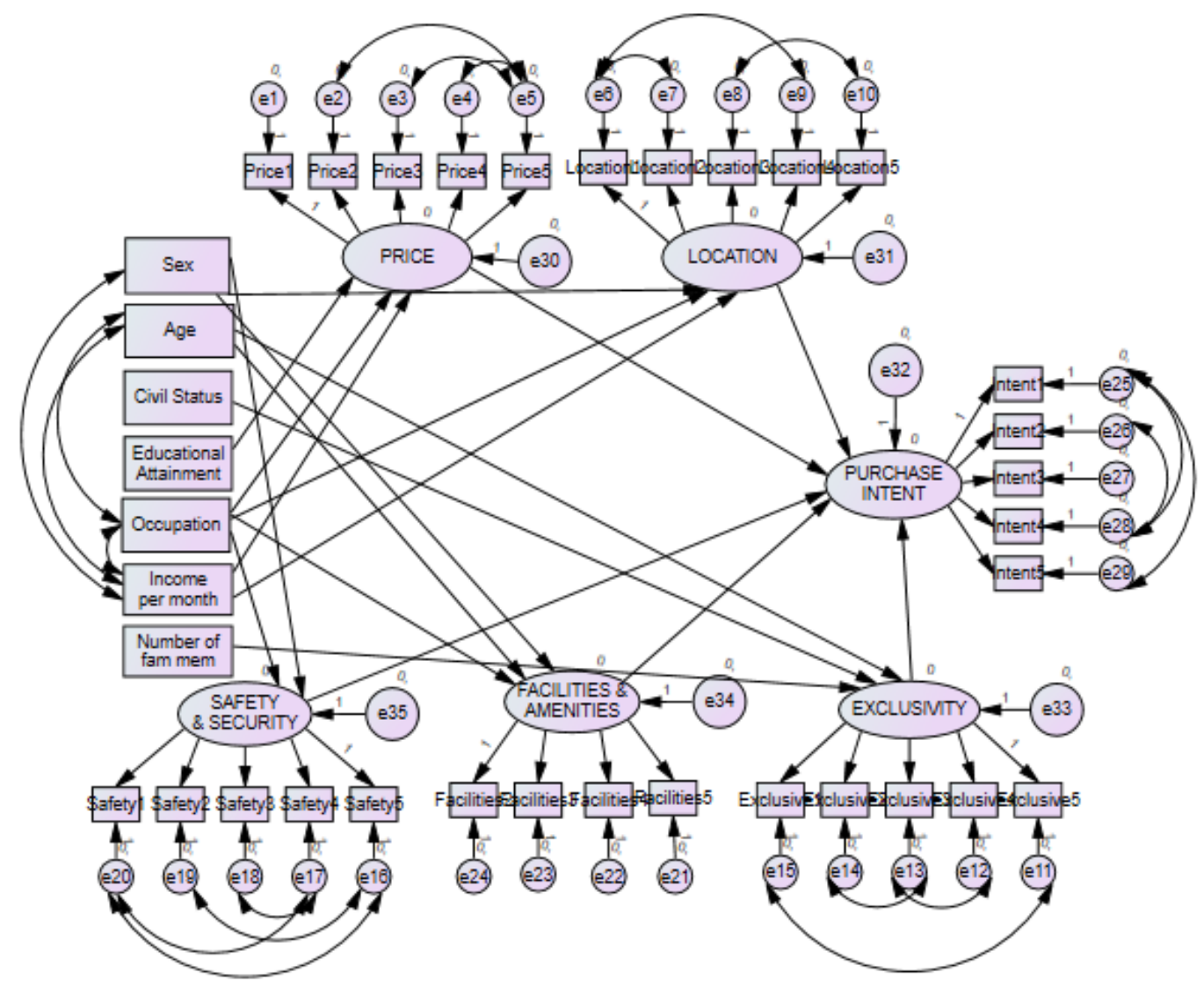

Figure 3. Emerging Model of The Causal Relationship Between Demographic Profile and Consumers' Choice Factors Towards Purchase Intention of Residential Property

\section{Hypothesis Testing}

Table 2 reveals the causal relationship of the demographic profile on consumers' choice particularly price, location, safety and security, facilities and amenities, and exclusivity.

Table 2: Causal Relationship of Demographic Profile on Consumers' Choice

\begin{tabular}{lcccc}
\hline & Estimate & SE & p-value & $\begin{array}{c}\text { Effect } \\
\text { size }\end{array}$ \\
\hline Sex $\rightarrow$ Location & 0.136 & 0.049 & $<0.01$ & 0.017 \\
Sex $\rightarrow$ Safety and Security & 0.258 & 0.049 & $<0.05$ & 0.011 \\
Sex $\rightarrow$ Facilities and & -0.195 & 0.049 & $<0.05$ & 0.010 \\
$\quad$ Amenities & 0.092 & 0.035 & $<0.05$ & 0.009 \\
Age $\rightarrow$ Facilities and Amenities & 0.193 & 0.049 & $<0.01$ & 0.036 \\
Age $\rightarrow$ Exclusivity & -0.117 & 0.049 & $<0.01$ & 0.120 \\
Civil status $\rightarrow$ Exclusivity & 0.093 & 0.049 & $<0.05$ & 0.015 \\
Educational Attainment $\rightarrow$ Price & -0.109 & 0.049 & $<0.05$ & 0.013 \\
Occupation $\rightarrow$ Price & -0.111 & 0.049 & $<0.05$ & 0.013 \\
Occupation $\rightarrow$ Location & -0.096 & 0.049 & $<0.05$ & 0.010 \\
Occupation $\rightarrow$ Safety \& Security & -0.106 & 0.049 & $<0.05$ & 0.008 \\
Occupation $\rightarrow$ Facilities \& amenities & 0.164 & 0.049 & $<0.01$ & 0.033 \\
Income per month $\rightarrow$ Price & 0.082 & 0.049 & $<0.05$ & 0.009 \\
Income per month $\rightarrow$ Location & -0.115 & 0.050 & $<0.01$ & 0.011 \\
Family Member $\rightarrow$ Exclusivity & & &
\end{tabular}


The emerging model identified the demographic profile variables affecting the consumers' choice factors on residential property. Analysis of the data reveal that the direct effect of educational attainment $(\beta=0.093, p<0.05)$, occupation $(\beta=-0.109, \mathrm{p}<0.05)$, and income per month $(\beta=0.164, \mathrm{p}<0.01)$ on price are significant. This indicates that educational attainment, occupation, and income per month have a significant relationship on price. Hence, $\mathrm{H}_{1 \mathrm{a}}$ is supported.

Results reveal that sex $(\beta=0.136, \mathrm{p}<0.01)$, occupation $(\beta=-0.111, \mathrm{p}<0.05)$, and income per month $(\beta=0.082, p<.05)$ have direct effect on location. This indicates that sex, occupation, and income per month have significant relationship on location. Therefore, $\mathrm{H}_{1 \mathrm{~b}}$ is supported.

Likewise, results show that sex $(\beta=0.258, p<0.05)$ and occupation $(\beta=-0.096, p<0.05)$ have direct effect on safety and security. This indicates that sex and occupation have significant relationship on safety and security. Hence, $\mathrm{H}_{1 \mathrm{c}}$ is supported.

The results reveal that sex $(\beta=-0.195, \mathrm{p}<0.05)$, age $(\beta=0.092, \mathrm{p}<0.05)$, and occupation $(\beta=-$ $0.106, \mathrm{p}<0.05)$ have direct effect on facilities and amenities. This indicates that sex, age and occupation have significant relationship on facilities and amenities. Hence, $\mathrm{H}_{1 \mathrm{~d}}$ is supported.

Also, the data reveal that age $(\beta=0.193, \mathrm{p}<0.01)$, civil status $(\beta=-0.117, \mathrm{p}<0.01)$, and number of family members $(\beta=-0.115, p<0.01)$ have direct effect on exclusivity. This indicates that age, civil status and number of family members have significant relationship on exclusivity. Hence, $\mathrm{H}_{1 \mathrm{e}}$ is supported.

Majid, Said and Daud (2012) studied the influence of consumers' demographic profile on buying residential property. Results showed that sex, civil status and occupation have significant impact on property criteria.

In contrary, other study showed that there is no significant relationship between demographic profile and identified important variables that influence residential property purchase (Manivannan \& Somasundaram, 2014).

Table 3: The Effect of Consumer's Choice on the Purchase Intention of the Respondent

\begin{tabular}{llcccc}
\hline & Estimate & SE & p-value & $\begin{array}{c}\text { Effect } \\
\text { size }\end{array}$ \\
\hline Price & $\rightarrow$ Intent & 0.208 & 0.061 & $<0.01$ & 0.054 \\
Location & $\rightarrow$ Intent & 0.126 & 0.064 & $<0.05$ & 0.010 \\
Safety and Security & $\rightarrow$ Intent & 0.112 & 0.053 & $<0.05$ & 0.036 \\
Facilities and Amenities & $\rightarrow$ Intent & 0.124 & 0.063 & $<0.01$ & 0.031 \\
Exclusivity & $\rightarrow$ Intent & 0.459 & 0.094 & $<0.01$ & 0.237 \\
\hline
\end{tabular}

Table 3 reveals that price $\left(\beta=0.208, \mathrm{p}<0.01, \mathrm{f}^{2}=0.054\right)$ has a direct effect on the purchase intention of the respondents to residential property. This indicates that price has a significant relationship on the purchase intention of the respondents to residential property. Hence, $\mathrm{H}_{2 \mathrm{a}}$ is supported. Study showed monetary concern mainly residential property price has a very strong impact on residential property purchase intention (Razak, Ibrahim, Hoo, Osman, \& Alias, 2013). Mortgage loans with long-term period have a positive influence on residential property 
purchase consumption behavior (Chambers, Garriga, \& Schlagenhauf, 2009, as cited in Lee, Ho, \& Chiu, 2016).

Also, data show that location $\left(\beta=0.126, \mathrm{p}<0.05, \mathrm{f}^{2}=0.010\right)$ has a direct effect on the purchase intention of the respondents to residential property. This indicates that location has significant relationship on the purchase intention of the respondents to residential property. Therefore, $\mathrm{H}_{2 b}$ is supported. The distance of residential property from stores, university, hospital, office and the commercial area is specified high significance in doing a purchasing choice (Kumar \& Khandelwal, 2018). A planned location will influence consumer fulfillment in purchasing (Pangenggar, Hidayat, \& Sendhang, 2014, as cited in Rachmawati, Shukri, Azam, \& Khatibi, 2019).

Likewise, safety and security $\left(\beta=0.112, \mathrm{p}<0.05, \mathrm{f}^{2}=0.036\right)$ has a direct effect on the purchase intention of the respondents to residential property. This indicates that safety and security have a significant relationship on the purchase intention of the respondents to residential property. Thereby, $\mathrm{H}_{2 \mathrm{c}}$ is supported. Residential property buyers are ready to buy a higher price house with safe and guarded area rather than an affordable residential property without security (San, 2016, as cited in Mariadas, Abdullah, \& Abdullah, 2019).

Results also show that facilities and amenities $\left(\beta=0.124, \mathrm{p}<0.01, \mathrm{f}^{2}=0.031\right)$ has a direct effect on the purchase intention of the respondents to residential property. This indicates that facilities and amenities have significant relationship on the purchase intention of the respondents to residential property. Hence, $\mathrm{H}_{2 \mathrm{~d}}$ is supported. Research showed that facilities have significant effect on purchasing attitude in residential property (Kamal \& Pramanik, 2015b).

Furthermore, exclusivity $\left(\beta=0.459 \mathrm{p}<0.01, \mathrm{f}^{2}=0.237\right)$ has a direct effect on the purchase intention of the respondents to residential property. This implies that exclusivity has a direct relationship on the purchase intention of the respondents to residential property. Thereby, $\mathrm{H}_{2 \mathrm{e}}$ is supported. Study recommends that numerous individuals may aim to settle in the top location, however affordability, distance and neighbourhood features take priority when it comes to looking for a residential property to buy (Ratchatakulpat, Miller, \& Marchant, 2009). Families are willing to buy a high-priced residential property for a good neighbourhood while selecting a property to buy (Thaker \& Sakaran, 2016, as cited in Mariadas, Abdullah, \& Abdullah, 2019).

\section{Conclusions}

The value of $\chi^{2} / \mathrm{df}$ stresses compatibility of the emerging model. The RMSEA value coincides within the acceptable range which associates the fitness of the proposed model. CFI, NFI and IFI values falls within the acceptable level, which indicates a good model fit of the proposed model.

Educational attainment, occupation, and income per month have a significant relationship on price. Hence, $\mathrm{H}_{1 \mathrm{a}}$ is supported. Sex, occupation, and income per month have significant relationship on location. Therefore, $\mathrm{H}_{1 \mathrm{~b}}$ is supported. Sex and occupation have significant relationship on safety and security. Hence, $\mathrm{H}_{1 \mathrm{c}}$ is supported. Sex, age and occupation have significant relationship on facilities and amenities. Hence, $\mathrm{H}_{1 \mathrm{~d}}$ is supported. Age, civil status and number of family members have significant relationship on exclusivity. Hence, $\mathrm{H}_{1 \mathrm{e}}$ is supported. 
Price has a significant relationship on the purchase intention of the respondents to residential property. Hence, $\mathrm{H}_{2 \mathrm{a}}$ is supported. Location has a significant relationship on the purchase intention of the respondents to residential property. Therefore, $\mathrm{H}_{2 b}$ is supported. Safety and security have a significant relationship on the purchase intention of the respondents to residential property. Thereby, $\mathrm{H}_{2 \mathrm{c}}$ is supported. Facilities and amenities have a significant relationship on the purchase intention of the respondents to residential property. Hence, $\mathrm{H}_{2 \mathrm{~d}}$ is supported. Exclusivity has significant relationship on the purchase intention of the respondents to residential property. Thereby, $\mathrm{H}_{2 \mathrm{e}}$ is supported.

\section{Recommendations}

It is initiated for residential property developers to apply the proposed model as a basis for marketing plan to be more competitive in the real estate industry. Furthermore, it is advised for future researchers to enhance the proposed model to further investigate the relationships of demographic profile and consumers' choice factors towards purchase intention.

\section{References}

Adrian, M. (2018, May 18). High-Rise Properties Vs Landed Houses: Which is Better?

Aliyu, A. A., Kasim, R. B., \& Martin, D. (2012). Impact of Violent Ethno-Religious Conflicts on Residential Property Value Determination in Jos Metropolis of Northern Nigeria: Regression Analysis Results. OIDA International Journal of Sustainable Development, IV(9), 35-50.

Al-Nahdi, T. S., Habib, S. A., \& Albdour, A. A. (2015, March 27). Factors Influencing the Intention to Purchase Real Estate in Saudi Arabia: Moderating Effect of Demographic Citizenship. International Journal of Business and Management, X(4).

Brennan, M., Olaru, D., \& Smith, B. (2014, September). Are Exclusion Factors Capitalised in Housing Prices? Case Studies on Transport Policy, II(2), 50-60.

Buckman, S., Trivers, I., Kayanan, C. M., \& Black, T. (2017, January). Hope for New Communities as an Alternative to Sprawl?: Insights from Developer Perceptions of Amenities in Future New Communities in the U.S. and U.K. Land Use Policy, LX, 233241.

Hair, J. F., Black, W. C., Babin, B. J., \& Anderson, R. E. (2010). Multivariate Data Analysis (Seventh Edition). Pearson.

Iman, A. H., Pieng, F. Y., \& Gan, C. (2012). A Conjoint Analysis of Buyers' Preferences for Residential Property. International Real Estate Review, XV(1), 73-105.

Kamal, M., \& Pramanik, S. A. (2015a). Customers' Intention towards Purchasing Apartment in Dhaka City, Bangladesh: Offering an Alternative Buying Intention Model. European Journal of Business and Management, VII(35).

Kamal, M., \& Pramanik, S. A. (2015b). Factors Affecting Customers to Buy Apartments in Dhaka City. Daffodil International University Journal of Business and Economics, IX(2), 37-49.

Kumar, Y., \& Khandelwal, U. (2018). Factors Affecting Buying Behaviour in the Purchase of Residential Property: A Factor Analysis Approach. International Journal on Customer Relations, VI(2), 27-32.

Lamudi. (2016, March 22). Six Issues Affecting the Philippines' Real Estate Sector in 2016. Real Estate News.

Lee, C. C., Ho, Y. M., \& Chiu, H. Y. (2016, April). Role of Personal Conditions, Housing Properties, Private Loans, and Housing Tenure Choice. Habitat International, LIII, 301-311. 
Liew, C., \& Haron, N. A. (2013, October). Factors Influencing the Rise of House Price in Klang Valley. IJRET: International Journal of Research in Engineering and Technology, II(10).

Majid, R., Said, R., \& Daud, M. N. (2012, January). The Impact Of Buyers' Demography On Property Purchasing. Journal of Surveying, Construction \& Property, III(2).

Manivannan, P., \& Somasundaram, M. (2014, September). Purchase of Residential Flats Factors Influencing the Decision of Buyers in Selected Cities in Tamil Nadu. International Research Journal of Business and Management - IRJBM, VII(9).

Mariadas, P. A., Abdullah, H., \& Abdullah, N. (2019). Factors Influencing the First Home Purchase Decision of Middle-Income Earners (M40) in Selangor, Malaysia. Journal of Social Sciences and Humanities, XVI(1), 1-11.

Masri, H., Nawawi, A. H., \& Sipan, I. (2016, October 31). Review of Building, Locational, Neighbourhood Qualities Affecting House Prices in Malaysia. Procedia - Social and Behavioral Sciences, CCXXXIV, 452-460.

Nasar, K. K., \& Manoj, P. K. (2015, May). Purchase Decision for Apartments: A Closer Look into the Major Influencing Factors. IMPACT: International Journal of Research in Applied, Natural and Social Sciences (IMPACT: IJRANSS), III(5).

Omagwa, J., \& Aduda, J. (2015). The Influence of Demographics on Owner-Occupied Housing Decisions: A Case of Apartment Households in Nairobi County, Kenya. Business \& Entrepreneurship Journal.

Rachmawati, D., Shukri, S., Azam, S. M., \& Khatibi, A. (2019, May 15). Factors Influencing Customers' Purchase Decision of Residential Property in Selangor, Malaysia. Management Science Letters, 1341-1348.

Ratchatakulpat, T., Miller, P., \& Marchant, T. (2009). Residential Real Estate Purchase Decisions in Australia: Is it More Than Location? International Real Estate Review, XII(3), 273-294.

Razak, I., Ibrahim, R., Hoo, J., Osman, I., \& Alias, Z. (2013, June). Purchasing Intention towards Real Estate Development in Setia Alam, Shah Alam: Evidence from Malaysia. International Journal of Business, Humanities and Technology, III(6), 66-75.

Salleh, N. A., Zoher, S. A., Mahayuddin, S. A., \& Abdul, Y. (2015). Influencing Factors of Property Buyer in Hillside Residential Development. Procedia - Social and Behavioral Sciences, CLXX, 586-595.

Tan, T. H. (2011, March 8). Neighborhood Preferences of House Buyers: The Case of Klang Valley, Malaysia. International Journal of Housing Markets and Analysis, IV(1), 5869.

Ticoalu, V. O., \& Tielung, M. V. (2015, December). The Analysis of Customer Purchase Intention of Houses Using Real Estate in Manado Based on Psychological Factors. $\operatorname{III}(4)$.

Vijayakumar, M., \& Subburaj, B. (2010, May). An Empirical Study of Consumer Awareness on Home Loan Agreement. European Journal of Economics, Finance and Administrative Sciences(20).

Wu, K. S., \& Teng, Y. M. (2011, September 4). Applying the Extended Theory of Planned Behavior to Predict the Intention of Visiting a Green Hotel. African Journal of Business Management, $V(17), 7579-7587$. 